\title{
Uppgifter som medierande artefakter inom yrkeslärarutbildningen
}

\author{
(Assignments as mediating artefacts \\ in vocational teacher education)
}

Katarina Lagercrantz All, Jan Pettersson, Marianne Teräs

Stockholms universitet, Sverige (katarina.lagercrantz@edu.su.se)

\begin{abstract}
Vocational teacher students accomplish a number of different assignments, which are meaningful for their learning and future work as vocational teachers. In Sweden, this education is relatively short (90 ECTS), partly conducted as distance education. The students enter the education with previous vocational knowledge and experiences. The aim of this study was to explore and describe assignments the students face during their vocational teacher education. The study questions focused on what is a form of assignment as mediating artefact and what kind of vocational knowledge is required? Conceptual background involved the concepts of mediation, artefact, vocational knowledge and knowledge culture. The data consisted of 13 course overviews. The results suggested dominance of individual written assignments. Even though some assignments were identified as 'doings' like teaching. The assignments were complex involving several vocational knowledge dimensions and the students needed to navigate between different knowledge domains. Furthermore, the students were asked to integrate their previous vocational knowledge with pedagogical knowledge. The assignments as mediating artefacts were connected to different knowledge cultures.
\end{abstract}

Keywords: artefacts, assignments, knowledge culture, vocational knowledge, vocational teacher education

NJVET, Vol. 8, No. 3, 78-97 Peer-reviewed article doi: 10.3384/njvet.2242-458X.188378 


\section{Introduktion}

De studie- och examinationsuppgifter som yrkeslärarstudenterna i likhet med andra studenter på universitet och högskola möter under utbildningen ligger till stora delar till grund för deras lärprocess (Brown, 2005). I uppgifterna tar studenterna inte enbart del av kunskapsinnehållet i de olika kurserna, de möter även den akademiska kunskapskulturen inom universitetet. Hur uppgifterna är utformade och vilken kunskap som efterfrågas i detsamma är av stor betydelse för studenternas utveckling till blivande yrkeslärare.

Som examinerade lärare undervisar studenterna elever på ett stort antal yrkesutbildningar inom gymnasieskolan och inom vuxenutbildning, med vitt skilda inriktningar. Yrkeslärarprogrammet i Sverige omfattar 90 högskolepoäng (hp), varav 60 hp är teoretiska kurser och 30 hp är verksamhetsförlagd utbildning (VFU) under vilken studenterna praktiserar i skolor som yrkeslärare under handledning. På Stockholms universitet är utbildningen delvis distansförlagd, med ett par campusförlagda undervisningsdagar i månaden. Det är en utbildningsform som innebär att utbildningen präglas av självständiga studier. Yrkeslärarstudenterna påbörjar lärarutbildningen med de kunskaper som ska ligga till grund för deras undervisning som blivande yrkeslärare. Studenternas utbildningserfarenheter skiljer sig dessutom åt. En del har ingen tidigare erfarenhet av högskolestudier, andra har en master eller är disputerade inom sitt yrkesområde, eller något annat ämnesområde. På grund av studenternas skillnader i bakgrund varierar också deras erfarenheter av skriftspråksanvändning (Ask, 2007).

De examensmål som ligger till grund för yrkeslärarprogrammet uttrycks i tre överordnade teman. Dessa handlar om att visa kunskap och förståelse, färdighet och förmåga, samt värderingsförmåga och förhållningssätt i relation till deras blivande yrke (Mål för yrkeslärarexamen, SFS 2011:186). De olika kursuppgifterna på yrkeslärarprogrammet grundar sig på de ovan nämnda examensmålen. Syftet med uppgifterna på yrkeslärarprogrammet vid Stockholms universitet är att utveckla studenternas kunskaper som blivande lärare. Således medierar uppgifterna de kunskaper som är en del av kunskapskulturen vid universitetet (Knorr Cetina, 1999).

Uppgifterna varierar och kan vara muntliga eller i form av rollspel, multimodala eller skriftliga. De skriftliga uppgifterna kan också skifta karaktär, i form av salstentamen, uppsats, essä eller referatformat (NSHU, 2010). De olika uppgifterna i kurserna är konstruerade utifrån olika syften som att studenterna ska redogöra för kunskaper och förmågor, eller med syfte att få möjlighet att utveckla egna reflektioner. Ett viktigt mål med de akademiska studierna är att studenterna ska utveckla det kritiska tänkandet (Moore, 2004).

Traditionellt används uppgifter för att kontrollera studenters kunskaper och deras lärande under och efter avslutad kurs (Boud \& Falchikov, 2007a). Eftersom studenternas examinationsuppgifter ligger till grund för betyget efter avslutad 
kurs får uppgifterna också en bedömningsfunktion. Uppgifterna har betydelse för det individuella, men även det sociala lärandet. Det senare avser att utveckla förmågan av interaktion genom den dialog en del uppgifter innefattar i form av kamratrespons- och granskning (Blomström, 2017). För att utveckla studenternas yrkeskunskaper som lärare efterfrågas i uppgifterna olika former av kunskap. Exempel på detta är att uppgifterna ger studenterna möjligheter att reflektera över egna erfarenheter samt koppla samman dessa med kunskaper utifrån kurslitteraturen.

Denna studie grundar sig på ett sociokulturellt perspektiv (Säljö, 2013). Utgångspunkten är att uppgifterna utgör pedagogiska verktyg som kommer att mediera lärandet av kunskaper och förväntas att bidra till studenternas utveckling i läraryrket.

\section{Syfte}

Det övergripande syftet med föreliggande studie är att beskriva uppgifterna som medierande artefakter inom en yrkeslärarutbildning. Detta sker genom att granska uppgifterna i kursernas studiehandledningar på yrkeslärarprogrammet.

Följande frågor är vägledande $i$ analysen:

- Vilken form antar uppgifterna som medierande artefakter?

- Vilka yrkeskunskaper efterfrågas i uppgifterna?

\section{Begreppsligt ramverk:}

\section{Mediering, artefakt, yrkeskunskap och kunskapskultur}

Vår utgångspunkt är att uppgifterna i studiehandledningarna bidrar till studenternas lärande och utifrån ett sociokulturellt perspektiv, utgör medierande artefakter. Begreppet artefakt, innebär enligt Säljö (2013, s. 13), att redskap i olika former är historiskt framväxta och kulturellt präglade. Som medierande artefakter kan uppgifterna anta olika former, utifrån varierande syfte för att mediera lärandet av yrkeskunskaper.

Begreppet mediering har sitt ursprung i Vygotskys (1978) arbete och forskning. Han skriver att högre psykologiska processer inte är direkta reflexer till ett stimuli, utan att de är sociokulturellt och historiskt medierade. Han visade hur barn använder olika materiella och symboliska kulturella redskap i sin verksamhet när de löser problem. Materiella redskap för lärande kan vara böcker eller olika texter. Symboliska redskap innebär framförallt språk som används i den aktuella verksamheten. Utifrån Vygotsky och det sociokulturella perspektivet utgår vi således från att uppgifterna i yrkeslärarutbildningen fungerar som medierande artefakter när det gäller lärandet av yrkeskunskaper. Vi anser dock att det 
även finns andra medierande artefakter som studenterna möter under utbildningen, som till exempel de redskap studenterna möter under den verksamhetsförlagda perioden under utbildningen (VFU). Det kan handla om digitala redskap, men också symboliska, som gällande normer och värderingar i skolorna, som är en del av yrkeskunnandet. Fokus i föreliggande studie är de uppgifter som förenar materiella och symboliska aspekter av yrkeskunskaper. Yrkeskunskaper handlar om att kunna fatta relevanta beslut i olika situationer, använda yrkesspråket och olika verktyg inom yrket (Lindberg, 2003a).

Genom den betydelse uppgifterna har för studenternas lärande av yrkeskunskaper kommer de uppgifter som studeras i denna studie att begreppsliggöras som medierande artefakter med epistemologiska funktioner. Det innebär att uppgifterna i yrkeslärarprogrammet som epistemologiska artefakter skapar och överför kunskaper. Uppgifterna i yrkeslärarprogrammet, i form av de medierande artefakterna, medverkar till det yrkeskunnande som den sociala praktiken efterfrågar av yrkeslärare. Begreppet sociala praktiker (Wenger, 1998) innebär en överenskommelse inom ett sammanhang om handlingar som representerar en gemensam syn på kunskap. Yrkeslärarstudenterna deltar i delvis olika yrkesgemenskaper och deltar därmed delvis i skilda sociala praktiker; till exempel yrkesgemenskap som snickare, akademisk gemenskap i universitetet och skolgemenskap som yrkeslärare under den verksamhetsförlagda delen av yrkeslärarprogrammet (Akre \& Ludvigsen, 2000).

Cole $(1996$, s. 117, 124) beskriver artefakter som materiella värden. I undervisningssammanhang kan detta representeras av texter och filmer som har modifierats under historien och som därmed är präglade av den kulturella och historiska kontexten. Det innebär att artefakter innefattas av olika kulturella meningar och betydelser. Den reifiering som sker genom att skriva och använda olika former av tecken, som ljud och film innebär att människor reifierar sina erfarenheter (Säljö, 2013, s. 52). Med uppgifterna kommer studenterna att sätta ord på sina erfarenheter och sina kunskaper vilket innebär en materiell reifiering som möjliggör kommunikation (Säljö, 2013, s. 89). I enlighet med Knuuttila (2005) kommer artefakter att vara betydelsefulla när det gäller att kommunicera med andra och med omgivningen. Exempel på detta är den kommunikation som sker mellan yrkeslärarstudenter, lärare och handledare under VFU-perioderna. Genom att studenterna lär sig att använda medierande redskap i form av uppgifterna kommer de att få nya erfarenheter och ny mening att bildas. Yrkeslärarprogrammet handlar till stora delar om att integrera yrkeslärarstudenternas tidigare yrkeskunskaper till yrkeslärarkunskaper.

Begreppet kunskap har en framträdande roll både inom vetenskap och utbildning. Hartman (2004, s. 32-33) beskriver tre olika former av kunskaper. Den teoretiska kunskapen som innebär att ha begreppsliga föreställningar av världen. Den praktiska kunskapen som handlar om att man vet hur man gör något, att man har förmågan att praktiskt uträtta något. Den tredje formen av kunskap 
Hartman beskriver är förståelsekunskap en kunskap som handlar om att man kan leva sig in i den andra personens situation. Billett (2018, s. 23-24) redogör för tre olika former av kunskaper inom yrkesutbildning: begreppskunskap (conceptual), procedurkunskap (procedural) och dispositionskunskap (dispositional). Den första formen innebär vad yrkespersoner vet, den andra vad de gör och den tredje formen handlar om vilket som är av intresse och vad som är av värde. Även om det är möjligt att analytiskt separera olika former av kunskaper, är dessa i realiteten integrerade.

Begreppet kunskapskultur innebär att kunskap konstrueras i ett socialt sammanhang, samt att kunskapskulturer förändras över tid och rum (Eliasson, 2009). Den rådande kunskapskulturen avgör vidare vad det är man efterfrågar i olika uppgifter. Knorr Cetina (1999) har studerat hur vetenskap producerar kunskaper via så kallade epistemologiska kulturer (epistemic cultures). Hennes definition $(1999$, s. 1) av epistemologiska kulturer är "cultures that create and warrant knowledge". Det innebär att de uppgifter som ingår i en utbildning skapar kunskaper, men också att kunskaper legitimeras.

I Eliassons avhandling (2009) studerades kunskapskulturer inom vårdlärarutbildningen och vilka föreställningar över tid som ansetts vara viktigt att kunna för blivande vårdlärare i en lokal kunskapskultur, i relation till statlig styrning. Begreppet kunskapskulturer definierades som gemensamma föreställningar och värden i kulturen, vilket innebär att handlingar, språket, texter och kategoriseringar blir kulturella yttringar. Dessa ger ledtrådar till kunskapskulturens föreställningar (Eliasson, 2009, s. 64). Resultaten visar hur kunskapskulturer inom vårdlärarutbildningen har skiftat under åren från en systematisk, objektiv kultur till en grupporienterad och studentaktiv kultur. Vidare framkommer i avhandlingen den starka kopplingen mellan kunskapskulturer och samhälleliga förändringar.

Kunskapskulturer är ett viktigt begrepp i föreliggande studie, eftersom det ligger till grund för hur uppgifter formas och konstrueras. Den rådande kunskapskulturen avgör uppgifternas utformning och vilka former och dimensioner av kunskaper som betonas. Den kommer att styra över vilka källor som är kopplade till studenternas uppgifter och vilka referenser som används och avkrävs studenterna i uppgifterna.

\section{Uppgifter i tidigare forskning}

När det gäller tidigare forskning om kunskaper och uppgifter inom yrkesutbildning har vi funnit ett fåtal som är direkt kopplade till uppgifter inom yrkeslärarutbildning. Vi har därför valt att relatera även till tidigare studier som handlar om uppgifter inom andra ämnesområden, som kan ses vara relevanta för denna studie. Vi inleder avsnittet med tidigare forskning som handlar om yrkeskun- 
nandet och lärarutbildningens kunskapsuppdrag. Det senare som det, enligt Jedemark (2007), finns en mindre benägenhet av att diskutera, vilket enligt forskaren kan vara resultatet av att det är yrkeskunskaper som ingår i en individualiserad yrkespraktik. Jedemark pekar på att det senmoderna samhället dock ställer andra krav på att kunna värdera och problematisera den egna verksamheten. Det är en utveckling som innebär att lärarutbildningens uppgift i högre grad handlar om att utveckla lärarstudenterna, bland annat när det gäller att reflektera över sitt eget och elevernas lärande.

Lindberg $(2003 a, b)$ har i sin forskning intresserat sig för yrkeskunnandet med fokus på yrkeselever. Hon har i sin avhandling (2003a) fokuserat på det centrala kunskapsinnehållet i yrkesutbildning och vad det är som yrkeseleverna ges möjligheter att lära sig under utbildningen. Vidare har Lindberg (2003b) studerat hur kunskaper är kopplade till yrkeskunnande i arbetslivet. Studiernas resultat visade att det kunnande som krävs i arbetslivet inte är något som enbart kan läras i skolan.

Hur uppgifterna är formulerade och därmed vilka färdigheter som efterfrågas har flera studier fokuserat på. Donham (2014) har studerat de ställda förväntningarna på studenterna i enlighet med instruktionerna i studentuppgifter. Analysen fokuserade på vilka färdigheter som uppgifternas instruktioner präglades av och om det var färdigheter som var typiska för uppgifter vid studier i högre utbildning. Tre teman identifierades som markerade färdigheter i instruktioner av uppgifter. Det första temat var informationskompetens med innebörd att studenterna kan hitta och analysera olika informationskällor och initiera undersökningar. Det andra temat visade på vikten av kunskaper i akademiskt skrivande. Det tredje temat handlade slutligen om studenternas attityd till sina studier som präglades av nyfikenhet, öppenhet, självförtroende och uthållighet.

Ask (2007) har i sin avhandling studerat nyblivna och erfarna lärarstudenters akademiska skriftspråk. Resultaten visade att uppgifternas formulering hade stor betydelse för studenternas möjligheter att visa på den kritisk-analytiska kompetensen som lärarutbildarna efterfrågade. Även om betydelse av kritiskt tänkande framförs som ett viktigt mål med universitetsstudier är det, som Moore (2004) skriver, inte klart uttalat vad detta innebär och inte tydligt hur detta på bästa sätt ska föras vidare till studenterna.

Dunlop och Sult (2013) har i sin studie undersökt uppgifter där studenter genom diskussioner, ges möjlighet att integrera olika ämnen som filmkunskap, religion och filosofi. Deras studie visade på den positiva effekt som uppgifter i form av ämnesövergripande diskussioner innebar för studenternas utveckling. Det sociala lärandets betydelse återkommer i forskningen. Bennett och Fisch (2013) fokuserade i sin studie på lärarstudenternas erfarenheter av uppgifter som handlade om lärarsamarbete (co-teaching). Resultatet visade att studenterna 
kunde utveckla sina kunskaper om lärarsamarbete genom att observera och kritiskt granska olika former av samarbete i klassrummet under deras verksamhetsförlagda utbildning.

Fidaldo och Turman (2017) har granskat hur studenterna i online-kurser använde olika alternativa former när de studerade och om de hade möjlighet att lämna in alternativ till skriftlig inlämning. Deras forskning visade att studenterna föredrog video, alternativt texter som inlärningsform. Studenterna ansåg att olika alternativa former av uppgifter kompletterade traditionella texter. Resultatet visade därmed på den positiva effekten av att använda olika former av uppgifter.

Alternativa uppgiftsformer och studentinflytande när det gäller uppgifter intresserar även Fulton och Schweitzer (2011). De undersökte motivationen hos studenter genom att dessa fick välja mellan tre olika uppgifter inom kursen programmering. Resultaten visade att studenterna upplevde en högre grad av tillfredsställelse med kursen om de kunde välja formen på uppgifterna själva, något som innebar en viss kontroll över vad de gjorde. Kostnaden för den motivationshöjande flexibiliteten är dock att det riskerar att inverka på deras lärande. Att låta studenterna välja, en "lättare" uppgift, kan innebära negativa konsekvenser för deras lärande och därmed även för deras slutbetyg.

Sammanfattningsvis visar den tidigare forskningen hur formen av uppgifter har inflytande på studenternas lärande. Även möjligheten att själv medverka vid utformningen av uppgiften påverkar studenternas utveckling positivt. I flera studier framkommer dock även risken med studentinflytande på uppgifter, hur denna kan sänka nivån på lärandet. Svårigheterna att formulera uppgifter som utvecklar den kritiskt analytiska kompetensen är ett återkommande tema.

\section{Metod och analys}

Studien bygger på en genomgång av de uppgifter i studiehandledningarna som ligger till grund för undervisningen på yrkeslärarprogrammets kurser under perioden höstterminen 2016 - vårterminen 2017. Analysen genomfördes utifrån de två forskningsfrågorna: Vilken form antar uppgifterna som medierande artefakter? Vilka yrkeskunskaper efterfrågas $i$ uppgifterna?

Analysen utifrån den första forskningsfrågan innebar en första genomläsning av 13 studiehandledningar. I denna fas gjordes en individuell analys av antalet studieuppgifter, formen på uppgifterna, om den var skriftlig eller performativ och om dessa skulle utföras individuellt, alternativt i grupp. Därefter diskuterades de individuella resultaten, för att komma fram till ett gemensamt resultat (se Tabell 1). 
Uppgifter som medierande artefakter inom yrkeslärarutbildningen

Tabell 1. Form av uppgifter inom studiehandledningarna.

\begin{tabular}{|c|c|c|}
\hline Namn på kursen & $\begin{array}{l}\text { Uppgifter antal } \\
\text { (antal med } \\
\text { betygsskala F-A) }\end{array}$ & Form \\
\hline $\begin{array}{l}\text { Bedömning och betygsättning av } \\
\text { yrkeskunnande } 7,5 \mathrm{hp}\end{array}$ & $6(1)$ & Skriftliga \\
\hline $\begin{array}{l}\text { Didaktik i yrkesutbildning, } \\
7,5 \mathrm{hp}\end{array}$ & $4(2)$ & $\begin{array}{l}\text { Skriftliga } \\
\text { Performativ/Rollspel }\end{array}$ \\
\hline Lärandeteorier, $7,5 \mathrm{hp}$ & $5(2)$ & Skriftliga \\
\hline $\begin{array}{l}\text { Skolans och yrkesutbildningens } \\
\text { historia, } 5 \mathrm{hp}\end{array}$ & $3(1)$ & Skriftliga \\
\hline $\begin{array}{l}\text { Sociala relationer i yrkesutbild- } \\
\text { ning ur ett mångfaldsperspektiv } \\
7,5 \mathrm{hp}\end{array}$ & $5(2)$ & $\begin{array}{l}\text { Skriftliga } \\
\text { Performativ/Rollspel }\end{array}$ \\
\hline $\begin{array}{l}\text { Kvalitetsarbete i yrkesutbildning } \\
\text { I, } 4 \mathrm{hp}\end{array}$ & $2(1)$ & $\begin{array}{l}\text { Skriftliga } \\
\text { Performativ }\end{array}$ \\
\hline $\begin{array}{l}\text { Kvalitetsarbete i yrkesutbildning } \\
\text { II, } 7,5 \mathrm{hp}\end{array}$ & $3(1)$ & $\begin{array}{l}\text { Skriftliga } \\
\text { Performativ/Opponering }\end{array}$ \\
\hline $\begin{array}{l}\text { Verksamhetsförlagd utbildning I, } \\
7,5 \mathrm{hp}\end{array}$ & 6 & $\begin{array}{l}\text { Skriftliga } \\
\text { Performativ/Film }\end{array}$ \\
\hline $\begin{array}{l}\text { Verksamhetsförlagd utbildning } \\
\text { II, } 7,5 \mathrm{hp}\end{array}$ & 7 & $\begin{array}{l}\text { Skriftliga } \\
\text { Performativ/Ljudinspelning }\end{array}$ \\
\hline $\begin{array}{l}\text { Verksamhetsförlagd utbildning } \\
\text { III, } 15 \mathrm{hp}\end{array}$ & 8 & Skriftliga \\
\hline Specialpedagogik, 7,5 hp & $3(1)$ & Skriftliga \\
\hline $\begin{array}{l}\text { Rättsliga och yrkesetiska aspekter } \\
\text { på skolan } 2,5 \mathrm{hp}\end{array}$ & 1 & Performativ/Diskussion \\
\hline Framträdande och retorik, 3,5 hp & 3 & $\begin{array}{l}\text { Skriftliga } \\
\text { Performativ/Muntligt }\end{array}$ \\
\hline
\end{tabular}

Analysen utifrån den andra forskningsfrågan innebar en induktiv, tematisk analys (Braun \& Clarke, 2006). I enlighet med den analysen identifierades och beskrevs yrkeskunskapsdimensioner som teman med koppling till data. Den induktiva tematiska analysen (Braun \& Clarke, 2006) bestod av sex faser: 
1. Genomläsning av data. Upprepad läsning av studiehandledningarna.

2. En första identifiering av koder som föreföll intressanta utifrån forskningsfrågorna.

3. Analys av de tidigare koderna och sortering av dessa i preliminära teman. Det visade sig att olika teman sammanföll till ett tema. Ett exempel på detta var temat Insikt, som istället för två teman, Insikt om andras lärande och Självinsikt, enligt vår tolkning, sammanföll i ett tema, vi benämner som Insikt.

4. Temana fastställdes efter ett antal revideringar.

5. Arbete med den slutgiltiga analysen av resultatet med tydligt definierade teman och tillhörande underbyggda data.

I analysen utifrån den modifierade induktiva tematiska analysen av uppgifterna i studiehandledningarna fann vi sju teman, vilka grundade sig på de olika dimensionerna av yrkeskunskaper som efterfrågades i uppgifterna (se Tabell 2).

Tabell 2. Tematisering av yrkeskunskapsdimensioner.

\begin{tabular}{|l|l|}
\hline Tema som yrkeskunskapsdimension & Koder för dimensioner \\
\hline Fakta utifrån kurslitteratur & Lagar, bestämmelse, teori, begrepp \\
\hline Begreppssammanhang & $\begin{array}{l}\text { Reflektera eller applicera över erfaren- } \\
\text { heter utifrån litteratur }\end{array}$ \\
\hline Social interaktion & $\begin{array}{l}\text { Diskussion, ta emot återkoppling och ge } \\
\text { återkoppling till en uppgift, perspektiv- } \\
\text { seende genom interaktion med andra }\end{array}$ \\
\hline Progression & $\begin{array}{l}\text { Skapa egen tråd, egen "dirigent" i texten, } \\
\text { forma eget perspektiv, fördjupning av } \\
\text { uppgift, alternativt fördjupning inom } \\
\text { kurs }\end{array}$ \\
\hline Görande & $\begin{array}{l}\text { Planera, genomföra, göra något, handla, } \\
\text { framställa }\end{array}$ \\
\hline Kritiskt förhållningssätt till kunskap & $\begin{array}{l}\text { Kritiskt reflektera kunskaper, ifrågasätta } \\
\text { och problematisera }\end{array}$ \\
\hline Insikt & $\begin{array}{l}\text { Reflektera över sitt eget yrkeskunnande } \\
\text { som lärare, insikt om elevers lärande. } \\
\text { Kunna reflektera över sin egen roll och } \\
\text { hur egna erfarenheter påverkar sin hand- } \\
\text { ling }\end{array}$ \\
\hline
\end{tabular}


Uppgifter som medierande artefakter inom yrkeslärarutbildningen

Den induktiva analysen utifrån de sju yrkeskunskapsdimensionerna genomfördes inledningsvis individuellt av de tre författarna. Därefter jämfördes de individuella resultaten och ett gemensamt resultat i form av ovanstående dimensioner fastställdes och kännetecken för dessa dimensioner arbetades fram.

\section{Resultat}

Form av uppgifter

Analysen av den första forskningsfrågan om uppgifternas form som medierande artefakter visade totalt 56 inlämningsuppgifter i 13 studiehandledningar (se Tabell 1).

Majoriteten av dessa uppgifter bestod av skriftliga uppgifter. Även de performativa uppgifterna innehöll, i de flesta fallen, skriftliga inslag i form av krav på reflektion. Kursernas omfattning varierade mellan 2,5 och $15 \mathrm{hp}$. De flesta kurserna använde en sjugradig betygsskala, från $\mathrm{F}$ till A. I VFU-kurserna (de verksamhetsförlagda kurserna) tillämpades en tregradig betygsskala, medan kurserna Framträdande och retorik samt Rättsliga och yrkesetiska aspekter på skolan använde betygen godkänd och underkänd. Olika moment integrerades i flera av de uppgifter som ingick $i$ kurserna. Exempel på detta var att uppgiften inleddes med att studenten skulle göra ett individuellt inlägg på lärplattformen, för att därefter kommentera och diskutera studiekamraternas inlägg. De skriftliga uppgifterna som medierande artefakter representerar också den skriftkultur som ingår i den akademiska kulturen inom universitetet (Ask, 2007). Mängden skriftliga uppgifter pekar på att den skriftliga kunskapskulturen dominerar inom yrkeslärarprogrammet, och att skriftlig kunskap berättigar yrkeslärarstudenternas yrkeskunskaper (Knorr Cetina, 1999).

Utifrån den första forskningsfrågan har vi har identifierat fyra olika former av uppgifter. Dessa utgjordes av gruppuppgifter, individuella skriftliga uppgifter, uppgifter i form av performativa handlingar samt en kombination av gruppuppgift och individuell uppgift. Ett exempel på en gruppuppgift är från kursen Framträdande och retorik i vilken studenterna övar på ett framträdande inför sin responsgrupp och gruppen ger konstruktiv respons under övningen. Ett exempel på individuella uppgifter i form av hemtentamen är från kursen Didaktik $i$ yrkesutbildning i vilken studenterna ska skriva en text om undervisning av andraspråkselever. En individuell uppgift i form av salstentamen är från kursen Sociala relationer. Det tredje exemplet är en uppgift vi benämner som performativ, i vilken studenterna filmar sin undervisning. Den fjärde formen av uppgifter, exempelvis från kursen Bedömning och betygssättning $i$ yrkesutbildning, innebär att studenterna påbörjar en text som de får återkoppling på i gruppen och från läraren. Studenten kan sedan arbeta vidare med texten individuellt för att lämna in den 
redigerade texten. Som medierande artefakter är uppgifterna, i enlighet med exemplen ovan, betydelsefulla när det gäller möjligheten att kommunicera med andra och med omgivningen i detta fall med andra studenter och lärare (Knuuttila, 2005).

\title{
Yrkeskunskapsdimensioner i uppgifter
}

I analysen av den andra forskningsfrågan identifierades sju olika yrkeskunskapsdimensioner. Dessa beskrivs som: Fakta, Begreppssammanhang, Social interaktion, Progression, Görande, Kritiskt förhållningssätt till kunskap och Insikt. Med uppgifterna som medierande artefakter efterfrågades olika källor. Exempel på olika källor var texter av varierande slag och studenternas egna erfarenheter från tidigare yrkeserfarenheter, men också erfarenheter från universitetet och från VFU-perioderna. I uppgifterna efterfrågades sålunda olika yrkeskunskapsdimensioner, vilket pekar på att de kunskaper som efterfrågades var mångdimensionella.

I följande fem exempel på uppgifter beskrivs de olika yrkeskunskapsdimensionerna utifrån den induktiva tematiska analysen (Braun \& Clarke, 2006).

\section{Exempel 1}

Exempel 1, nedan, är från en av uppgifterna i kursen Didaktik i yrkesutbildning och handlar om att identifiera didaktiska utmaningar.

\begin{abstract}
Du kan närma dig denna uppgift ganska fritt men din text skulle kunna se ut på detta sätt: Identifiera en eller flera didaktiska utmaningar utifrån kurslitteraturen och eventuellt egna erfarenheter. Resonera om hur didaktiska strategier kan användas för att hantera dessa utmaningar. Utgå från litteraturen men underbygg resonemanget med egna tankar och erfarenheter. Du kan gärna använda begreppen principer, omständigheter och handlingar utifrån Bronäs \& Runebou (2010) för att din text ska bli mer analytisk. Omständigheter kan då ofta likställas med din utmaning, t ex "omotiverade elever". Vilka handlingar/strategier kan man då använda som lärare? Och går det att identifiera några bakomliggande principer bakom dessa handlingar? (Uppgift i kursen Didaktik i yrkesutbildning)
\end{abstract}

I uppgiften ovan ska studenterna utgå från kurslitteraturen och från egna erfarenheter, något som efterfrågar yrkeskunskapsdimensioner som Fakta utifrån kurslitteratur och även Begreppssammanhang. Uppgiften efterfrågar även en dimension i form av Kritiskt förhållningssätt till kunskap, det vill säga att resonera i texten utifrån olika perspektiv. Ett exempel på detta i uppgiften är: Vilka handlingar/strategier kan man då använda som lärare? I uppgiftsformuleringen ges exempel på hur texten kan struktureras, något som kan vara en stötta för studenterna när det gäller att disponera texten. Det finns även förslag på hur texten ska kunna "bli mer analytisk". Detta kan tolkas som att ge studenterna anvisningar hur de ska utveckla det akademiska skrivandet och den akademiska kunskapskulturen (Ask, 2007). 
Uppgifter som medierande artefakter inom yrkeslärarutbildningen

\section{Exempel 2}

Kursen Verksamhetsförlagd utbildning (VFU) I omfattar 7,5 hp. Under kursen är studenterna ute i de tilldelade skolorna för att aktivt delta i undervisningen. Kursen omfattar 25 arbetsdagar, varav tre av dessa är reserverade för de fyra skriftliga uppgifterna samt de tre loggboksinläggen under kursen. Studenterna ska även skriva en individuell handlingsplan. Kursen är den första av tre VFU-perioder under utbildningen.

För att bli godkänd måste du beskriva en planering för en lektion/undervisningstillfälle skriftligt där du knyter an till minst ett nationellt styrdokument, motiverar val av undervisningsmetoder, tydligt beskriver genomförandet samt utvärderar såväl planering som genomförande. Frågor som du bör besvara är:

- Vilket innehåll fokuserade du och varför?

- Vilka undervisningsformer valde du och varför?

- Hur upplevde du genomförandet?

- Vilken respons gav eleverna?

- Specifika svårigheter som uppstod?

- Vad blev bra, vad skulle kunna förbättras?

Du ska också lägga in en filmsnutt från din lektion (ca 2-3 minuter) och kommentera det inspelade genom att relatera till något/några av de förväntade studieresultaten. Tänk på att om dina elever syns i bild måste du ha deras tillåtelse. (Uppgift i kursen VFU I)

I exempel 2 efterfrågas den yrkeskunskapsdimension som faller under temat Görande. Detta tema innefattar att studenterna ska framställa något, i detta fall planera, motivera, och filma en undervisningssituation. De ska vidare skriftligen beskriva och reflektera över sin handling vid detta tillfälle. I uppgiften efterfrågas även Fakta utifrån kurslitteratur (styrdokument) och Kritiskt förhållningssätt till kunskap. I uppgiften ingår att besvara frågor som "vad blev bra och vad kunde förbättras". Det sistnämnda kan tolkas som en uppmaning att diskutera ur olika perspektiv och motivera de gjorda valen. Vår tolkning är att i uppgiften efterfrågas yrkeskunskapsdimensioner i form av Görande, den praktiska handlingen, Fakta i form av styrdokument, samt även kunskapsdimensionen Ett kritiskt förhållningssätt. Det innebär att uppgiften strävar efter att integrera studenternas tidigare yrkeskunnande med yrkeslärarkunskaper och att utveckla studenternas yrkeslärarkunskaper. Detta visar att yrkeskunskaper integrerar teori och praktik och att yrkeskunskaper är kopplade till arbetslivet (Lindberg, 2003b).

\section{Exempel 3}

I kursen Bedömning och betygssättning av yrkeskunnande var en av uppgifterna formulerad som att studenterna kan "Ta hjälp av följande litteratur".

Välj en undervisningssituation som du nyligen varit med om under din VFU I eller under arbete som yrkeslärare. Beskriv situationen så som du minns den. Använd följande struktur: - vilken/vilka uppgifter ska eleven/eleverna lösa? - vad ska eleven/eleverna lära sig genom uppgiften? - vilka instruktioner (muntliga/skriftliga) har de fått? - vilken koppling finns det till mål och kunskapskrav i styrdokument 
(aktuell ämnesplan och kurs)? Reflektera sedan över situationen utifrån följande frågeställningar: -vad lär sig eleven? -hur vet du det? -vilken kvalitet på arbetet har eleven uppnått i relation till kunskapskrav? -vad kan du eventuellt inte bedöma?

(Uppgift i kursen Bedömning och betygsättning av yrkeskunnande)

I exemplet är dimensionen Begreppssammanhang synlig. I uppgiften efterfrågas att sätta in begrepp från litteraturen och från styrdokument (begreppet "kunskapskrav" är från gymnasieprogrammets läroplan) i ett sammanhang. Även kunskapsdimension Insikt, ingår i uppgiften genom att lärarstudenten uppmanades att reflektera över hur hen kan veta vad eleven lär sig.

De ovan givna exemplen visar på den ofta förekommande komplexiteten i uppgifterna, eftersom det i samma uppgift efterfrågas flera olika yrkeskunskapsdimensioner. I den ovan angivna uppgiften handlade det om att koppla målen och kunskapskraven i styrdokumenten till aktuell uppgift. Detta efterfrågar faktakunskap om aktuella styrdokument samt att kunna applicera dessa till den aktuella elevuppgiften, vilket förutsätter kunskap om att integrera begrepp i ett sammanhang. Som medierande artefakt medierar uppgiften lärandet av olika yrkeskunskapsdimensioner.

\section{Exempel 4}

Nästa exempel från samma kurs som ovan visar på Progression och Social interaktion inom en uppgift.

Examinationsuppgiften 1. Versionen läggs in Mondo/Inlämningsmapp senast den $15 / 3$, samt skickas samma dag via mail till de kursdeltagare som fått i uppgift att läsa examinationsuppgiften.

Examinationsuppgiften redovisas muntligt den 22/3. Ni förväntas vid detta tillfälle kunna diskutera er examinationsuppgift utifrån ett konstruktivt såväl som kritiskt förhållningssätt. Ni får i uppgift att läsa några kurskamraters examinationsuppgifter och lämna några konstruktiva synpunkter efter modellen två positiva synpunkter och en synpunkt på något ni tycker kan utvecklas/förbättras. Ett schema för vilka examinationsuppgifter ni ska läsa kommer att delas ut. En bearbetad slutversion av examinationsuppgiften lämnas in Mondo/Uppgifter den 29/3. (Uppgift i kursen Bedömning och betygssättning av yrkeskunnande)

I denna uppgift ingår yrkeskunskapsdimensionen Social interaktion genom återkopplingen till studiekamraternas texter som uppgiften uppmanar till. Den återkoppling som studenterna förväntas ge till kurskamraterna och erhålla på sitt eget arbete innebär även att uppgiften omfattar yrkeskunskapsdimensionerna Progression och Kritiskt förhållningssätt till kunskap. När studenterna i uppgiften förväntas ge medstudenter konstruktiv kritik innebär detta mediering av de språkliga artefakterna inom yrkeslärarutbildningen. Den reifiering som därmed sker ger möjlighet att vidga och fördjupa kommunikationen på olika plan, som yrkeslärarstudent och som blivande lärare inom sitt område (Säljö, 2013). 
Uppgifter som medierande artefakter inom yrkeslärarutbildningen

\title{
Exempel 5
}

Exemplet nedan från den tredje Verksamhetsförlagda kursen (VFU III) riktar sig till studenternas kommande lärararbete.

\begin{abstract}
Skriv en text som ska vara något av en "programförklaring" för ditt kommande lärararbete. Hur vill du arbeta för att främja lärande? Vilka teorier/perspektiv har du tagit till dig som du vill bygga din undervisning på? Vilken forskning har inspirerat dig? Vilka värderingar/etiska riktlinjer anser du vara viktiga? Vilka arbetssätt/arbetsformer har du upplevt som positiva?
\end{abstract}

I din text måste du ge exempel från din egen undervisning. Du måste också relatera till litteratur från utbildningen och ha med minst fem olika titlar (men gärna flera referenser till varje titel). Skriv minst $2 \mathrm{~A} 4$ och lägg in under rätt flik i VFUportföljen senast 5 juni. (Uppgift i kursen VFU III)

Exemplet visar på kunskapsdimensionerna Insikt, Fakta utifrån kurslitteratur och Begreppssammanhang. Även här exemplifieras uppgifternas komplexitet, eftersom den efterfrågar att knyta samman olika kunskapsdimensioner. Vidare är detta exempel på en styrd uppgift med detaljerade instruktioner om antalet referenser och sidor. Detta är instruktioner vilka kommer att prägla uppgiften och som kan ge exempel på en akademisk kunskapskultur (Knorr Cetina, 1999). Som medierande artefakt ska denna uppgift lägga en grund för studenternas roll som yrkeslärare (Säljö, 2013). Frågan i uppgiften "Vilka arbetssätt/arbetsformer har du upplevt som positiva?" innebär att uppgiften integrerar den sociala praktiken som yrkeslärare med den akademiska praktiken inom universitetet.

\section{Sammanfattning av analys}

Analysen av den första forskningsfrågan, Vilken form antar uppgifterna som medierande artefakter, klargör att uppgifterna framförallt bestod av skriftliga uppgifter som innebar individuellt producerande av texter. Ett antal av dessa uppgifter innefattade dock inslag av en kollaborativ process, i och med möjligheterna som gavs att få respons från medstudenter och från lärare för att utveckla texten vidare. I dessa uppgifter fick på så sätt studenterna stöttning att komma vidare i uppgiften. Samtliga uppgifter krävde referenser till kurslitteraturen vilket också kunde ses som en stötta för studenterna i arbetet med uppgifterna. Genom kravet på att referera till kurslitteraturen kunde å andra sidan uppgifterna ses som styrda och normativa. Det fanns heller ingen eller liten möjlighet för studenterna att välja mellan olika former av uppgifter och flexibiliteten inom uppgiften var på så sätt begränsad.

I analysen av den andra forskningsfrågan, Vilka yrkeskunskaper efterfrågas i uppgifterna, framkom en tydlig koppling mellan litteratur och praktik. Här tydliggjordes att uppgifterna ofta var komplexa, genom att skilda kunskapsdimensioner var integrerade med varandra. Flertalet uppgifter var formulerade som att studenten skulle utgå från egna erfarenheter och koppla dessa till litteraturen. Detta innebar att integrera de egna erfarenheterna med litteraturen, en form av 
kunskapsdimension vi benämner som Begreppssammanhang. Genom att skriva om de egna erfarenheterna och koppla dessa till litteraturen, ges möjlighet att få tillgång till nya begrepp. De medierande redskap som studenterna tillägnar sig genom litteraturen, ger möjlighet till en reifiering, att sätta ord på erfarenheter, något som ger möjlighet att i resonera med sig själv och andra på ett annat sätt (Säljö, 2013, s. 52).

\section{Diskussion}

Syftet med denna studie var att beskriva uppgifterna som medierande artefakter inom ett yrkeslärarprogram. Vi frågade efter vilken form uppgifterna antar som medierande artefakter, samt vilka yrkeskunskaper som efterfrågades i uppgifterna.

Resultaten visar på en dominans av skriftliga uppgifter som representerar vad Knorr Cetina (1999) benämner som den akademiska kunskapskulturen. Detta lyfter frågan hur den akademiska kunskapskulturen sammanfaller med den blivande kunskapskulturen i yrkeslärares verksamhet. Boud och Falchikov (2007b) diskuterar traditionens makt när det gäller examinationsformer och menar att det finns ett behov av att diskutera hur väl dessa stämmer överens med den praktik som studenterna ska verka inom. Det kan därför vara värt att diskutera mängden av skrivuppgifter och den betydelse som den akademiska skriftkulturen har i utbildningen i förhållande till de performativa uppgifterna i yrkeslärarprogrammet. Skrivuppgifter kan dock ses fylla en viktig funktion när det gäller att sätta ord på erfarenheter och på det sättet kunna kommunicera med andra. Den fixering av språkliga uttryck som skrivandet innebär ger också möjligheten till en inre diskussion som kan leda till en djupare egen reflektion (Säljö, 2013). Den relativt ensidiga skriftliga uppgiftsformen kan å andra sidan i enlighet med Fidaldo och Turman (2017) inverka negativt på studenternas lärprocess. En mer varierad form av uppgifter kan vara positivt ur flera aspekter (Fulton \& Schweitzer, 2011). Resultatet kan tolkas som att uppgifterna i sin formulering visar på normativa inslag snarare än att ge studenterna frihet att själva forma uppgifterna.

Uppgifterna under VFU-perioderna innefattade dock en större variation med performativa inslag än under de universitetsförlagda kurserna. Även om instruktionerna och formen i dessa uppgifter är fastställda har studenterna möjligheter att välja sammanhanget och innehållet, något som på så sätt innebär en viss frihet vad de skall fokusera på och vilka referenser de kan välja. Detta kan innebära att uppgifterna å ena sidan kan upplevas som enklare, men även mer stimulerande, genom att studenterna själva i viss utsträckning kan välja fokus. Fulton och Schweitzer (2011) argumenterar för möjligheten att en ökad frihet för studenterna att välja formen på uppgifterna kan öka motivationen och meningsskapandet. $\AA$ andra sidan finns en risk, utan tydligt krav på vilken kunskap som efterfrågas i uppgiften, att studenten förenklar uppgiften. Den kunskapsmediering 
som uppgiften skulle vara ett led i går på det sättet förlorad (Säljö, 2013). För de studenter med ingen eller liten erfarenhet av akademiskt skrivande och den akademiska kunskapskulturen kan den friare formen av uppgiftsbeskrivning vara alltför bristfällig för att understödja studenternas lärprocess (Fulton \& Schweitzer, 2011). Ask (2007) pekar på vikten av att kravet på den kritiskt analytiska förmågan tydligt framgår i uppgifterna och menar att det inte kan ses som självklart för studenterna att uppfatta att detta ingår som krav. Hur uppgiften är formulerad har således betydelse för resultatet och studenternas förståelse av de förväntningar som ställs på dem (Ask, 2007, s. 157).

Resultaten visade att de medierande uppgifterna inom yrkeslärarprogrammet hör samman med en kunskapskultur som är kopplad till både en akademisk och en praktisk tradition (se Knorr Cetina, 1999; Eliasson, 2009). ^̊ ena sidan krävs skriftliga uppgifter med krav på referenser och akademiskt skrivande och å andra sidan uppgifter under VFU-perioder med friare form och tydlig koppling till läraryrket. Som beskrivits omfattar också uppgifterna att studenterna kopplar till tidigare yrkeserfarenheter. Kravet på akademiskt skrivande och den tillhörande kunskapskulturen som yrkeslärarstudenterna möter på universitet, kan vara främmande från den tidigare kunskapskulturen inom deras tidigare yrkesutövande. För yrkeslärarstudenterna handlar det således om att integrera och skifta mellan olika kunskapskulturer såsom deras tidigare som yrkesutövare inom det tidigare yrket visavi det akademiska sammanhanget inom universitetet och den kunskapskultur som präglar de skolor inom vilka studenterna gör VFUperioderna. För yrkeslärarstudenterna handlar det således om att skifta, inte endast mellan kunskapskulturer, utan även mellan olika sociala praktiker (Wenger, 1998), något som ställer krav på studenternas förmåga att anpassa sig. För att studenterna ska komma i åtnjutande av delaktigheten inom den sociala praktiken som omfattar yrkeslärare, ställs krav att uppgifterna medierar de kunskaper som efterfrågas.

Den andra forskningsfrågan handlade om vilka yrkeskunskaper som efterfrågades i uppgifterna. Resultatet visade att uppgifterna var sammansatta till sin karaktär, det vill säga att de uttryckte krav på flera olika kunskapsdimensioner och ämnesområden, i samma uppgift. I resultatet framkom att studenterna förväntades ta del av kurslitteratur, men även av styrdokument, lagar och regler. Att ta del av dessa kan ses utgöra en grund för läraryrket.

En kunskap som återkommande efterfrågades i uppgifterna handlade om att kunna integrera de tidigare yrkeskunskaperna med de pedagogiska kunskaperna (Billett, 2018). Uppgifternas beskrivningar löd följaktligen att studenterna skulle koppla samman kunskapen om innehåll, kunskapen om pedagogik, kunskapen om pedagogiskt innehåll och kunskap om kursplaner med deras tidigare kunnande (se Dunlop \& Sult, 2013; Lindberg, 2003b). Det innebar att med uppgiften integrera kunskaperna från det tidigare yrket till yrkeslärarkunnandet. Wenger (1998) beskriver detta som en form av gränsöverskridande kunskaper. 
Den sammansatta kunskapen som återkommer i uppgifterna får antas ha sin grund i tanken att yrkeskunskaper, i detta fall yrkeslärarkunskaper, inte bara är kopplade till den akademiska kunskapstraditionen, utan även till arbetslivet (Lindberg, 2003b). Detta är ytterligare ett exempel på hur yrkeslärarprogrammet med dess sammansatta uppgifter kommer att tillhöra olika kunskapskulturer. Dessa kulturer ska dock inte ses som helt åtskilda från varandra, utan kulturer som påverkar varandra. Studenterna kommer under VFU-perioder på olika sätt att föra vidare de teoretiska artefakterna som de tagit del av under universitetskurserna.

Ett flertal av uppgifterna handlade om att studenterna, utöver att koppla till sina tidigare yrkeserfarenheter, också ska koppla till personliga erfarenheter med pedagogiskt och didaktiskt resonemang samt koppla detta till litteraturen. Att i uppgifterna på det sättet kunna förhålla sig till det som kan beskrivas som professionellt, personlig och även privat ställer krav på självinsikt och en kritisk analys och kritiskt tänkande (Moore, 2004). Det finns en risk, som vi kan se, att den kritiska- analytiska kompetensen som efterfrågas i en del av uppgifterna, inte var tydligt framskrivna i uppgiftsformuleringen.

Den Sociala interaktionen var ett återkommande inslag i de uppgifter som bestod av att ge respons på varandras texter. Även uppgifter i form av forumdiskussioner på universitetets lärplattform faller under denna kunskapsdimension. Genom att studenterna i uppgifterna stimuleras till social interaktion med kurskamrater och lärare ges möjlighet till perspektivmedvetenhet och kritiskt tänkande (Dunlop \& Sult, 2013). Ett socialt lärande påtalas vidare ge möjlighet att utveckla förmågan att kunna röra sig mellan innehåll, begrepp, metoder och kunskapsområden.

Den studieform, delvis distansstudier, som erbjuds yrkeslärarstudenterna innebär krav på skrivande och på självständighet. Ask (2007) pekar på att det i första hand är interpersonella möten med lärare och medstuderande som ger stöttning i det akademiska skrivandet. Den ofta enskilt utformade uppgiften kan därmed ifrågasättas när det gäller att gynna den efterfrågade kunskapsdimensionen, i form av den kritiska analytiska förmågan. Det är möjligt att det för nya studenter kan behövas tydligare guidning när det gäller uppgiftsinstruktioner, vad som är förväntningarna på de efterfrågade kunskaperna, samt vilka krav som följer med universitetsstudier.

I analysen av uppgifterna framkom att ingen uppgift innehöll frågan "varför". En varför-fråga skulle kunna stödja studenterna att ifrågasätta, värdera och bidra till att utveckla lärandet av kritiskt tänkande som är viktiga examensmål i utbildningen. Detta är något Moore (2004) efterfrågar och som framförs som ett viktigt mål med de akademiska studierna. Liksom i tidigare forskning och i enlighet med resultatet i vår studie kan vi uppfatta bristande stöd när det gäller att utveckla studenternas skrivande och riktning mot kritisk analys. Detta kan verka 
negativt speciellt för studenterna med mindre erfarenhet av akademisk kunskapskultur. En möjlighet att utveckla och stödja studenternas utveckling kan vara att ge möjlighet till fler uppgifter som innebär processkrivande och uppgifter som har en tydligare progression inom samma uppgift.

Ett bidrag med vår studie är förståelsen av hur medierande artefakter, i form av uppgifter kan utveckla yrkeslärarstudenterna i deras blivande yrkesroll som lärare. Ett annat bidrag med studien är att belysa de olika kunskapskulturerna som yrkeslärarstudenterna möter och att kunna röra sig mellan olika kunskapskulturer. Vidare visar resultatet hur uppgifterna ställer krav på att integrera olika kunskaper och kunna hantera olika kunskapsdimensioner under yrkeslärarprogrammet.

I den här studien har vi enbart undersökt och analyserat formen och de kunskaper som efterfrågades i uppgifterna i yrkeslärarutbildningen. Vi har således inte undersökt studenternas svar eller deras lärande och ej heller utfallet av de instruktioner som följer med uppgifterna, något som vore intressant att studera $\mathrm{i}$ en kommande studie. Ett annat intressant projekt vore att ta del av studenternas erfarenheter av uppgifterna de möter under sin utbildning och hur de upplever sitt lärande

\section{Om författarna}

Katarina Lagercrantz All arbetar som universitetslektor vid Stockholms universitet. Hon undervisar och handleder framförallt blivande yrkeslärare. Hennes forskningsintresse är yrkesutbildning, framförallt inom vård- och omsorgssektorn och speciellt med inriktning mot vuxnas lärande och frågor som rör integration och delaktighet. Hon har tidigare arbetat som vård- och omsorglärare inom vuxenutbildningen.

Jan Pettersson arbetar som universitetsadjunkt vid Stockholms universitet. Han undervisar och handleder blivande yrkeslärare. Hans forsknings- och utvecklingsintresse innefattar frågor kring bedömning och didaktik inom yrkesutbildning. Tidigare har han arbetat som yrkeslärare inom byggprogrammet $\mathrm{i}$ Stockholmsområdet.

Marianne Teräs, docent, arbetar som universitetslektor vid Stockholms universitet. Hon undervisar och handleder bland annat blivande yrkeslärare. Hennes forskningsintresse innefattar profession- och yrkesutbildning och speciellt interkulturella frågor inom dessa utbildningar. Tidigare har hon arbetat som postdoktoral forskare vid Helsingfors universitet och som vårdlärare på Social- och hälsovårdsskolan i Helsingfors. 


\section{Referenser}

Akre, V. \& Ludvigsen, S.R. (2000). Att lära praktisk medicin. I K. Nielsen \& S. Kvale (Red.), Mästarlära lärande som social praxis (s. 124-138). Lund: Studentlitteratur.

Ask, S. (2007). Vägar till ett akademiskt skriftspråk. Växjö: Växjö University Press.

Bennett, D. \& Fisch, A. (2013). Infusing coteaching into the general education field experience. Interdisciplinary Journal of Teaching and Learning, 3(1), 18-37.

Billett, S. (2018). Student readiness and the integration of experiences in practice and education settings. I S. Choy, G-B. Wärvik \& V. Lindberg (Red.), Integration of vocational education and training experiences: Purposes, practices and principles. (s. 19-40). Singapore: Springer.

Blomström, W. (2017). Akademiskt läsande och skrivande. Lund: Studentlitteratur.

Boud, D. \& Falchikov, N. (2007a). Aligning assessment with long-term learning. Assessment \& Evaluation in Higher Education, 31(4), 339-413.

Boud, D. \& Falchikov, N. (2007b). Assessment for the longer term. I D. Boud \& N. Falchikov (Red.), Rethinking assessment in higher education learning for the longer term (s. 3-13). New York: Routledge Taylor \& Francis Group.

Braun, V. \& Clarke, V. (2006). Using thematic analysis in psychology. Qualitative Research in Psychology, 3(2), 77-101.

Brown, S. (2005). Assessment for learning. Learning and Teaching in Higher Education, (1), 81-89. Hämtad 16 februari 2018 från

http://eprints.glos.ac.uk/3607/1/LATHE\%201.\%20Assessment\%20for\%20Learning\%20Brown.pdf

Dunlop, L. \& Sult, L. (2013). Juggling and the art of the integrative assignment. Journal of Learning Communities Research and Practice, 1(1), Article 7. Hämtad 1 juli 2017 från http://washingtoncenter.evergreen.edu/lcrpjournal/vol1/iss1/7

Cole, M. (1996). Cultural psychology: A once and future discipline. Cambridge, MA: Harvard University Press.

Donham, J. (2014). College ready: What can we learn from first-year college assignments? An examination of assignments in Iowa colleges and universities. School Library Research, 17, 1-21. Hämtad 1 juli 2017 från

http://www.ala.org/aasl/sites/ala.org.aasl/files/content/aaslpubsandjournals/slr/vol17/SLR_CollegeReady_V17.pdf

Eliasson, E. (2009). Metod, personlighet och forskning: Kontinuitet och förändring $i$ vårdlärarutbildarnas kunskapskultur 1958-1999. Doktorsavhandling 159. Stockholm: Stockholms universitet, Pedagogiska Institutionen.

Fidaldo, P. \& Turman, J. (2017). Reaching students in online courses using alternative formats. International Review of Research in Open and Distributed Learning, 18(2), 139-161. 
Uppgifter som medierande artefakter inom yrkeslärarutbildningen

Fulton, S. \& Schweitzer, D. (2011). Impact of giving students a choice of homework assignments in an introductory computer science class. International Journal for the Scholarship of Teaching and Learning, 5(1), Article 20. Hämtad 1 juli 2017 från https://doi.org/10.20429/ijsotl.2011.050120

Hartman, J. (2004). Vetenskapligt tänkande: Från kunskapsteori till metodteori. Lund: Studentlitteratur.

Jedemark, M. (2007). Lärarutbildningens olika undervisningspraktiker: En studie av lärarutbildares olika sätt att praktisera sitt professionella uppdrag. Doktorsavhandling. Lund: Lunds Universitet, Pedagogiska Institutionen.

Lindberg, V. (2003a). Yrkesutbildning i omvandling En studie av lärandepraktiker och kunskapstransformationer. Doktorsavhandling. Stockholm: Lärarhögskolan i Stockholm, Institutionen för Samhälle, Kultur och Lärande.

Lindberg, V. (2003b). Vocational knowing and the content in vocational education. International Journal of Training Research, 1(2), 40-61.

Knorr Cetina, K. (1999). Epistemic cultures: How the sciences make knowledge. Cambridge, MA: Harvard University Press.

Knuuttila, T. (2005). Models as epistemic artefacts: Towards a non-representationalist account of scientific representation. Philosophical studies 8. Helsinki: University of Helsinki.

Moore, T. (2004). The critical thinking debate: How general are thinking skills? Higher Education Research \& Development, 23(1), 3-18.

NSHU. (2010). Examination - en exempelsamling: Vanliga och mindre vanliga sätt att värdera studieresultat. Hämtad 16 februari 2018 från http://kursutveckling.se/dok/nshu_Examination.pdf

SFS 2011:186. Svensk författningssamling. Hämtad 16 februari 2018 från

https://www.lagboken.se/Lagboken/sfs/sfs/2011/100-199/d_758682-sfs2011_186-forordning-om-andring-i-forordningen-2010_542-om-andring-iforordningen-2010_541-om

Säljö, R. (2013). Lärande och kulturella redskap: Om lärprocesser och det kollektiva minnet. Lund: Studentlitteratur.

Wenger, E. (1998). Communities of practice: Learning, meaning and identity. Cambridge: Cambridge University Press.

Vygotsky, L.S. (1978). The development of perception and attention. I M. Cole, V. John- Steiner, S. Scribner \& E. Souberman (Red.), Mind in society: The development of higher psychological processes (s. 31-37). Cambridge, MA: Harvard University Press. 